\title{
Protection of telomeres 1 protein levels are associated with telomere length in gastric cancer
}

\author{
KIYOMU FUJII ${ }^{1}$, TOMONORI SASAHIRA ${ }^{1}$, YUKIKO MORIWAKA ${ }^{1}$, \\ NAOHIDE OUE ${ }^{2}$, WATARU YASUI ${ }^{2}$ and HIROKI KUNIYASU ${ }^{1}$ \\ ${ }^{1}$ Department of Molecular Pathology, Nara Medical University School of Medicine, \\ Kashihara, Nara; ${ }^{2}$ Department of Molecular Pathology, Hiroshima University \\ Graduate School, Hiroshima, Japan
}

Received December 3, 2007; Accepted January 25, 2008

\begin{abstract}
Protection of telomeres 1 (Pot1) is a telomereassociated protein, which binds to the single-stranded DNA extensions of telomeres and regulates telomere length. Pot 1 production was examined and compared with telomere length in gastric cancer. Pot1 production and telomere lengths were assessed in 5 human gastric cancer cell lines by immunoblotting and Southern blotting, respectively. Pot1 intracellular localization was examined with protein fractionation. Pot1 index and telomere volume were examined in human gastric mucosa and cancer by immunohistochemistry and in situ hybridization. Pot1 protein levels, which were lower than those in the lymphocytes of healthy persons, were significantly correlated with telomere length in gastric cancer cells $(\mathrm{P}=0.0167)$. Pot 1 protein was mainly detected in the nuclear fraction and increased by $\mathrm{G} 2 / \mathrm{M}$ blocking with nocodazole in MKN28 cells. Pot1 indexes were correlated with telomere volumes in gastric cancers $(\mathrm{P}<0.0001)$. Pot 1 index was decreased in gastric epithelia distant from cancer $(84 \pm 14 \%)$, in peritumoral epithelia $(72 \pm 24 \%)$, and in stage I-II $(39 \pm 14 \%)$ and stage III-IV $(23 \pm 14 \%)$ gastric cancers $(\mathrm{P}<0.0001)$. Pot 1 index was lower in stage III-IV than in stage I-II gastric cancers $(\mathrm{P}<0.05)$. Pot1-low cases showed advanced cancer invasion $(\mathrm{P}<0.05)$. Thus, Pot 1 production was closely associated with telomere length in gastric mucosa and cancers. Pot1 might be a good in situ marker for the examination of cell-specific telomere length.
\end{abstract}

Correspondence to: Dr Hiroki Kuniyasu, Department of Molecular Pathology, Nara Medical University School of Medicine, 840 Shijocho, Kashihara, Nara 634-8521, Japan

E-mail: cooninh@zb4.so-net.ne.jp

Abbreviations: Pot1, protection of telomeres 1; H. pylori, Helicobactor pylori; hTERT, human telomerase reverse transcriptase; hTR, human telomerase RNA

Key words: telomere, telomere length, gastric cancer

\section{Introduction}

The telomere is a repetitive sequence of TTAGGG, located at the chromosomal ends. Telomere reduction is closely associated with aging, inflammatory, regenerative, and carcinogenic processes in various cells and tissues (1-4). In our previous study, the telomeres were reduced at various levels in the epithelial cells in the gastric mucosa in comparison with mucosa-infiltrating lymphocytes, smooth muscle cells, and endothelial cells (5). In particular, telomeres were notably reduced in the intestinal metaplasia epithelium with Helicobactor pylori (H. pylori) infection, in which human telomerase reverse transcriptase (hTERT) protein expression was found in association with a marked reduction of telomeres (5). Human telomerase RNA (hTR) is also expressed in relation to $H$. pylori infection in intestinal metaplasia (6). Telomere shortening, expression of hTR and hTERT, and telomerase activation are commonly found in gastric cancer (7). From these findings, we can hypothesize that the earliest stage of gastric cancer development might be associated with telomere reduction.

Protection of telomeres 1 (Pot1) is a telomere-associated protein, which is isolated from ciliated protozoa (8). Pot1 binds to the single-stranded G-rich DNA extensions of the telomere with its N-terminal DNA-binding domain, and protects the chromosomal ends from chromosomal instability $(8,9)$. Pot1 localizes to telomeres in the interphase nuclei of human cells (10) or during periods of the cell cycle when t-loops are thought to be present (11). Pot1 regulates the telomere length: TRF1 regulates Pot1-binding with singlestrand telomere DNA and Pot1 controls telomerase-mediated telomere elongation by $c i s$-inhibition of telomerase (12-14). We previously reported that 3 ' telomeric overhang signals decreased in accordance with decreases in Pot 1 expression levels and telomere shortening (15). In gastric cancer, the mRNA expression of Pot 1 is associated with telomere length and cancer progression $(15,16)$.

In the present study, we demonstrated that Pot1 protein level were closely associated with telomere length in gastric cancer cells and were decreased in gastric mucosal epithelia and gastric cancer. 


\section{Materials and methods}

Cell culture. Human gastric cancer cell lines, MKN28, MKN45, TMK1, HSC39 were routinely maintained in RPMI-1640 (Sigma Chemical Co., St. Louis, MO) containing $10 \%$ fetal bovine serum (FBS, Sigma Chemical Co.) under the conditions of $5 \% \mathrm{CO}_{2}$ in air at $37^{\circ} \mathrm{C}$. Lymphocytes used as the control for Pot 1 expression and telomere length were obtained from the peripheral blood of 3 healthy volunteers, whose mean age was matched to gastric cancer patients (2 men and 1 woman, 59, 61 and 65 years of age, mean: 61.7 years). Lymphocytes $\left(1 \times 10^{7}\right)$ were collected from each volunteer and mixed for examination.

Patients and tumor specimens. Twenty-four gastric cancer patients (12 stage I-II and 12 stage III-IV cases; 15 men and 9 women, 52-78 years of age, mean: 63.6 years) were randomly selected from the cases analyzed in our previous study (5). A formalin-fixed, paraffin-embedded surgical specimen containing the deepest invasion site was chosen from the tissue specimens of each patient. Tumor staging and histopathological grading were classified according to the UICC TNM classification system (17) and Lauren's classification (18). Their medical records and prognostic follow-up data were obtained from the patient database maintained by the hospital.

Immunoblot analysis. Whole-cell lysates were prepared as described previously (19). Fifty-microgram lysates were subjected to immunoblot analysis in $12.5 \%$ sodium dodecyl sulfate-polyacrylamide gels followed by electrotransfer onto nitrocellulose filters. The filters were incubated with primary antibodies and then with peroxidase-conjugated IgG antibodies (Medical and Biological Laboratories, Nagoya, Japan). An $\alpha$-tubulin antibody was used to assess the levels of protein loaded per lane (Oncogene Research Products, Cambridge, MA). The immune complex was visualized by a CSA system (Dako, Carpinteria, CA). Anti-protection of telomeres 1 (Pot1) antibodies (Santa Cruz Biotechnology, Santa Cruz, CA) were used as the primary antibodies.

Southern blot analysis. High molecular weight genomic DNA was extracted with a DNA Extraction Kit (Stratagene Cloning System, La Jolla, CA). DNA was digested with HinfI (Takara Biomedicals, Tokyo, Japan), electrophoresed on $0.8 \%$ agarose-TAE gels, and blotted onto nitrocellulose filters. The filters were hybridized with (TTAGGG) $)_{4}$ probe labeled with biotin at the 5' end (Sigma Genosys, Ishikari, Japan), which was detected with peroxidase-conjugated avidine and visualized with an ECL system (both from Dako). We estimated the telomere length as the peak signal using Kodak Digital Science 1D software (Eastman Kodak Company, New Haven, CT). DNA ladders (2.5-kb and 1-kb) (Takara Biomedicals) were used for the measurement of peak telomere length.

Intracellular localization. MKN28 cells grown in culture dishes were treated with or without nocodazole (Alexis Biochemicals, San Diego, CA; $100 \mathrm{ng} / \mathrm{ml}$ for $24 \mathrm{~h}$ ). The cells were re-suspended in $500 \mu 1$ of STKM buffer [50 mM Tris
$\mathrm{HCl} \mathrm{pH} 7.5,25 \mathrm{mM} \mathrm{KCl}, 5 \mathrm{mM} \mathrm{MgCl}_{2}, 0.25 \mathrm{M}$ sucrose, $10 \mu \mathrm{g} / \mathrm{ml}$ leupeptin, $50 \mu \mathrm{g} / \mathrm{ml}$ phenylmethylsulfonyl fluoride (PMSF)] and stroked 150 times in dounce pestles. After a $1,000 \times \mathrm{g}, 5$-min centrifugation, the supernatant was centrifugated at $40,000 \times \mathrm{g}$ for $1 \mathrm{~h}$ at $4^{\circ} \mathrm{C}$ to separate the membrane fraction (pellet) and the cytosol fraction (supernatant). The pellet was re-suspended by $1000 \mathrm{x}$ g-spin into hypertonic buffer (25 mM Tris $\mathrm{HCl} \mathrm{pH} 7.8,10 \mathrm{mM} \mathrm{KCl,} 5 \mathrm{mM} \mathrm{MgCl}_{2}$, $10 \mu \mathrm{g} / \mathrm{ml}$ leupeptin, $50 \mu \mathrm{g} / \mathrm{ml} \mathrm{PMSF}$ ) and incubated for $5 \mathrm{~min}$ on ice followed by the addition of the same amount of 2X STKM buffer. After centrifugation at 40,000 x g for $1 \mathrm{~h}$ at $4{ }^{\circ} \mathrm{C}$, the pellet was re-suspended with nuclear extraction buffer (20 mM Hepes pH 7.9, $420 \mathrm{mM} \mathrm{NaCl}, 1.5 \mathrm{mM}$ $\mathrm{MgCl}_{2}, 0.2 \mathrm{mM}$ EDTA, $0.5 \mathrm{mM}$ DTT, 25\% glycerol) as the nuclear fraction. Loading amounts were monitored by Coomassie blue staining of the same amount of the proteins dot-blotted onto nitrocellulose membrane.

Immunohistochemistry. Immunohistochemistry was performed as previously described (20). Sections (4 $\mu \mathrm{m}$ thick) of each specimen were mounted on ProbeOn slides for ISH (Fisher Scientific, Pittsburgh, PA). An immunoperoxidase technique was used following antigen retrieval with microwave $(1,000 \mathrm{~W})$ treatment for $10 \mathrm{~min}$ three times in citrate buffer ( $\mathrm{pH}$ 6.0). After blocking endogenous peroxidase activity with $3 \% \mathrm{H}_{2} \mathrm{O}_{2}$-methanol for $15 \mathrm{~min}$, the specimens were rinsed with phosphate-buffered saline (PBS). Anti-Pot1 antibody (Santa Cruz Biotechnology) diluted to $0.5 \mu \mathrm{g} / \mathrm{ml}$ was used as the primary antibody. After a 2-h incubation at room temperature, the slides were rinsed with PBS and incubated at room temperature for $1 \mathrm{~h}$ with a secondary antibody conjugated to peroxidase (1:200) (anti-goat IgG antibody, Medical and Biological Laboratories Co. Ltd). After being rinsed with PBS, all specimens were colordeveloped with diaminobenzidine (DAB) solution (Dako). Immunostaining of all specimens was performed simultaneously to ensure the same antibody reaction and DAB exposure conditions. Nuclear immunoreactivity was judged as positive. Pot 1 positivity was examined as follows: 1,000 nuclei were observed in Pot 1 immunostained slides under x200 magnification microscopy. The Pot 1 index was designated as a percentage. Data of telomere volume in gastric cancer cases were derived from our previous study (5).

Telomere volume. Telomere volume was determined by fluorescent in situ hybridization (FISH). Sections (10 $\mu \mathrm{m}$ thick) of each specimen were mounted on ProbeOn slides (Fisher Scientific, Pittsburgh, PA) for ISH. The telomere repeat probe (TTAGGG) $)_{4}$ was labeled with fluorescein isothiocyanate (FITC) on the 3'-tail (EspecOligo Service, Tsukuba, Japan) (5). The probe was diluted to $20 \mu \mathrm{g} / \mathrm{ml}$ by probe hybridization solution [50\% formamide (Sigma Chemical Co.), 0.5 M NaCl, 5\% polyethylene glycol 8000 [Sigma Chemical Co.)]. The specimens were dewaxed and dehydrated with xylene and $100 \%$ ethanol. They were then hydrated in Tris-buffered saline (Sigma Chemical Co.) and digested with $0.2 \%$ pepsin- $2 \mathrm{M} \mathrm{HCl}$ (Dako) for $1 \mathrm{~h}$ at $37^{\circ} \mathrm{C}$, and then subjected to RNase A (10 $\mu \mathrm{g} / \mu \mathrm{l}$, Takara Biomedicals) treatment at $37^{\circ} \mathrm{C}$ for $10 \mathrm{~min}$. Specimens were then heated with probe solution at $100^{\circ} \mathrm{C}$ for $5 \mathrm{~min}$, cooled to $4^{\circ} \mathrm{C}$ for 
Table I. Pot1 protein levels and telomere length in gastric carcinoma cell lines.

\begin{tabular}{lcc}
\hline Cell line & Pot1 level $(\%)^{\mathrm{a}}$ & Telomere length $(\mathrm{kb})$ \\
\hline MKN28 & 47 & 4.7 \\
MKN45 & 42 & 3.8 \\
TMK1 & 31 & 3.1 \\
HSC39 & 25 & 2.8 \\
Lymphocytes & 100 & 9.9 \\
\hline
\end{tabular}

aSignal density of immunoblotting was standardized with that in lymphocytes, which was set to $100 \%$.
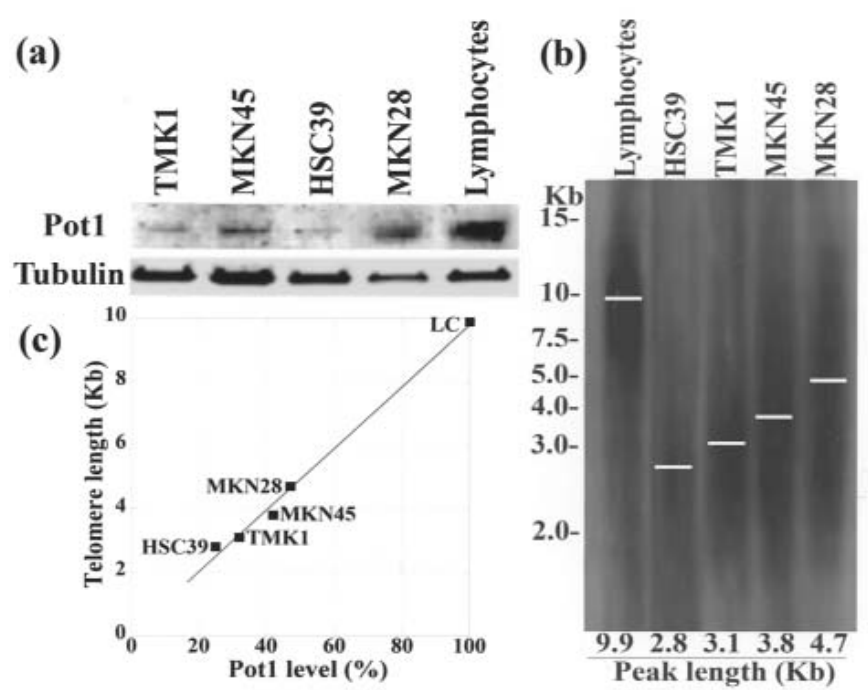

Figure 1. Pot1 production and telomere length in human gastric cancer cell lines. (a) Pot1 production was detected by immunoblotting in gastric cancer cells. Lymphocytes were examined as the normal control. Tubulin was detected as the loading control. (b) Telomere length was examined by Southern blot analysis in gastric cancer cells. Peak length is designated by a white line in each lane. (c) Correlation between Pot1 production and telomere length was examined. Pot 1 production was designated as a percentage of that in lymphocytes (LC).

$15 \mathrm{~min}$, and then maintained at $37^{\circ} \mathrm{C}$ for $2 \mathrm{~h}$. The specimens were rinsed five times with $1 \mathrm{X}$ standard sodium chloride/ sodium citrate at $45^{\circ} \mathrm{C}$.

Specimens hybridized with the (TTAGGG) $)_{4}$ probe were examined with 520-nm light for FITC. Specimen images were stored on a computer and processed (Fig. 1a). Briefly, 100 nuclei were identified from the images, and the hybridization signals were scanned as inverted gray-scale images by means of NIH Image software (National Institute for Health, Bethesda, MD). The mean signal density and mean nuclear area of the 100 nuclei were calculated. The mean density was divided by the mean nuclear area $\left(\mu \mathrm{m}^{2}\right)$ to adjust for differences in the DNA amounts of the identified nuclei. The resulting value was considered to be representative of the telomere density of the tissue and was termed telomere volume to distinguish it from the telomere length determined by Southern blot analysis (5).
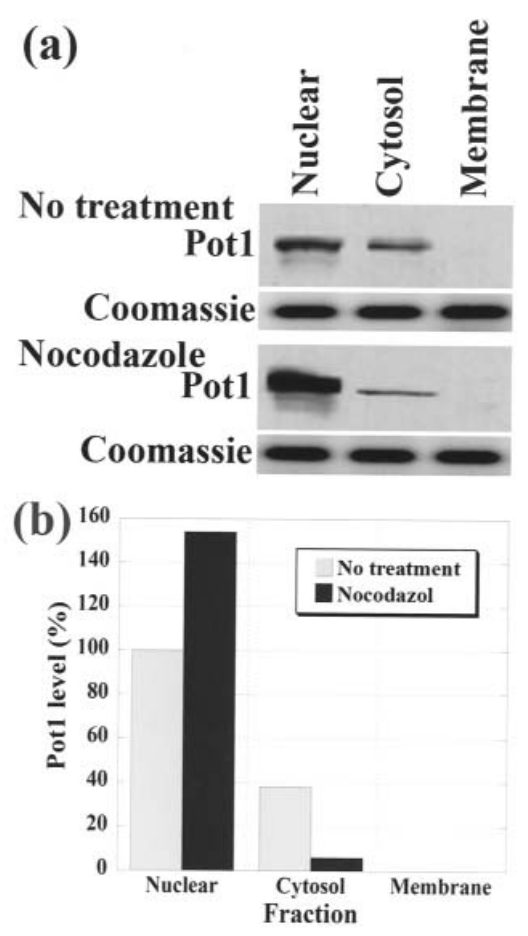

Figure 2. Intracellular localization of Pot1 was examined using fractionated protein extraction of MKN28 gastric cancer cells. (a) Pot1 was detected in each protein fraction by immunoblotting. Loading amounts were monitored by Coomassie blue staining of the same amount of protein dot-blotted onto nitrocellulose membrane. To increase G2/M phase cells, MKN28 cells were treated with nocodazole (100 ng/ml, 24 hrs). (b) Relative Pot 1 protein levels. Pot 1 level in the nuclear fraction of untreated cells was set to $100 \%$.

Statistical analysis. Statistical significance was examined by the Spearman's Rank test, the two-tailed, unpaired MannWhitney U test, and Fisher's exact test using InStat software (Graphpad Software, Los Angeles, CA). Statistical significance was defined as a two-sided P-value of $<0.05$.

\section{Results}

Pot1 production and telomere length in gastric cancer cells (Table I). We first examined Pot1 protein production in gastric carcinoma cells (Fig. 1a). Pot1 expression in gastric cancer cells was decreased in comparison with human lymphocytes. The telomere lengths of these cells were next examined (Fig. 1b). The gastric cancer cell lines showed reduced telomere length in comparison with the lymphocytes of healthy persons. We compared Pot1 expression with telomere length in the cells (Fig. 1c). Pot1 production was significantly correlated with telomere length (Spearman $\mathrm{R}=0.9998, \mathrm{P}=0.0167)$.

Intracellular localization of Potl in gastric cancer cells. Next, the intracellular localization of Pot1 was examined in MKN28 cells (Fig. 2). In untreated MKN28 cells, Pot1 protein was detected in the nuclear and cytosol fraction. Pot 1 was not detected in the membrane fractions. When MKN28 cells were treated with nocodazole to stop the cell cycle at $\mathrm{G} 2 / \mathrm{M}$ phase, Pot 1 was increased in the nuclear fraction, whereas it was decreased in the cytosol fraction. 


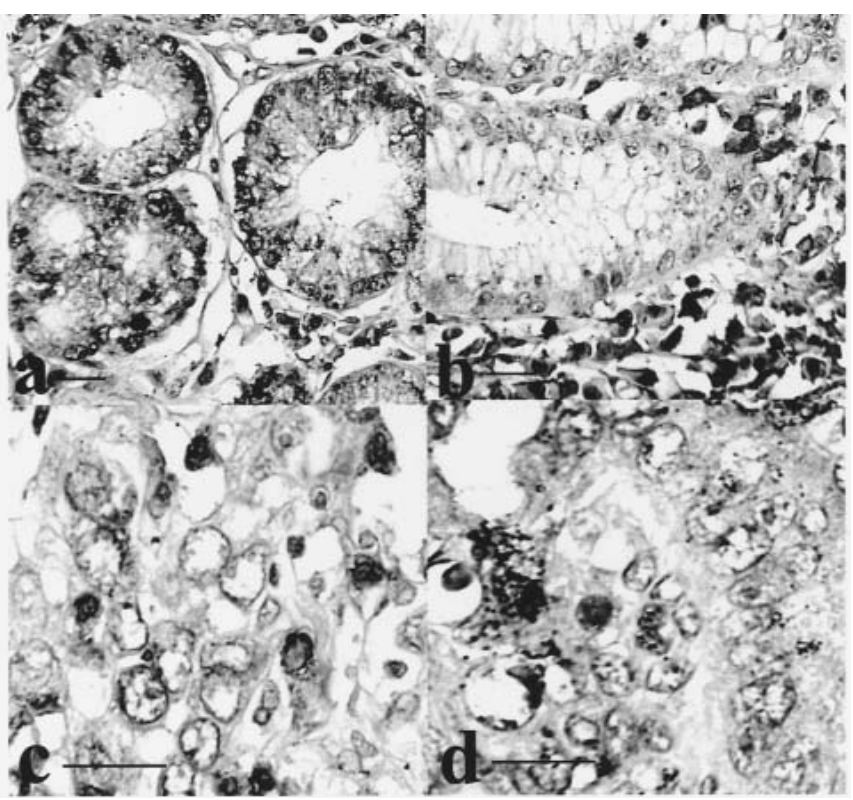

Figure 3. Immunohistochemistry of Pot1 in gastric mucosa and cancer. (a) Gastric mucosa distant from the tumor. (b) Peritumoral mucosa. (c) Earlystage gastric cancer. (d) Advanced gastric cancer. Nuclear immunoreactivity was judged as positive. Bar, $50 \mu \mathrm{m}$.

Table II. Pot1 positivity and telomere volume in human gastric cancer.

\begin{tabular}{|c|c|c|c|}
\hline Case no. & $\begin{array}{c}\text { Pathological } \\
\text { stage }\end{array}$ & $\begin{array}{c}\text { Pot1 } \\
\text { positivity }(\%)\end{array}$ & $\begin{array}{c}\text { Telomere } \\
\text { volume }(\%)\end{array}$ \\
\hline 1 & I & 58 & 68 \\
\hline 2 & I & 54 & 65 \\
\hline 3 & I & 52 & 41 \\
\hline 4 & I & 47 & 76 \\
\hline 5 & I & 45 & 62 \\
\hline 6 & I & 42 & 52 \\
\hline 7 & I & 40 & 58 \\
\hline 8 & I & 31 & 71 \\
\hline 9 & II & 25 & 33 \\
\hline 10 & II & 18 & 52 \\
\hline 11 & II & 16 & 42 \\
\hline 12 & III & 48 & 60 \\
\hline 13 & III & 43 & 65 \\
\hline 14 & III & 38 & 70 \\
\hline 15 & III & 33 & 52 \\
\hline 16 & III & 30 & 21 \\
\hline 17 & III & 24 & 25 \\
\hline 18 & III & 24 & 47 \\
\hline 19 & III & 18 & 35 \\
\hline 20 & IV & 12 & 43 \\
\hline 21 & IV & 10 & 18 \\
\hline 22 & III & 8 & 33 \\
\hline 23 & IV & 8 & 23 \\
\hline 24 & IV & 5 & 23 \\
\hline
\end{tabular}
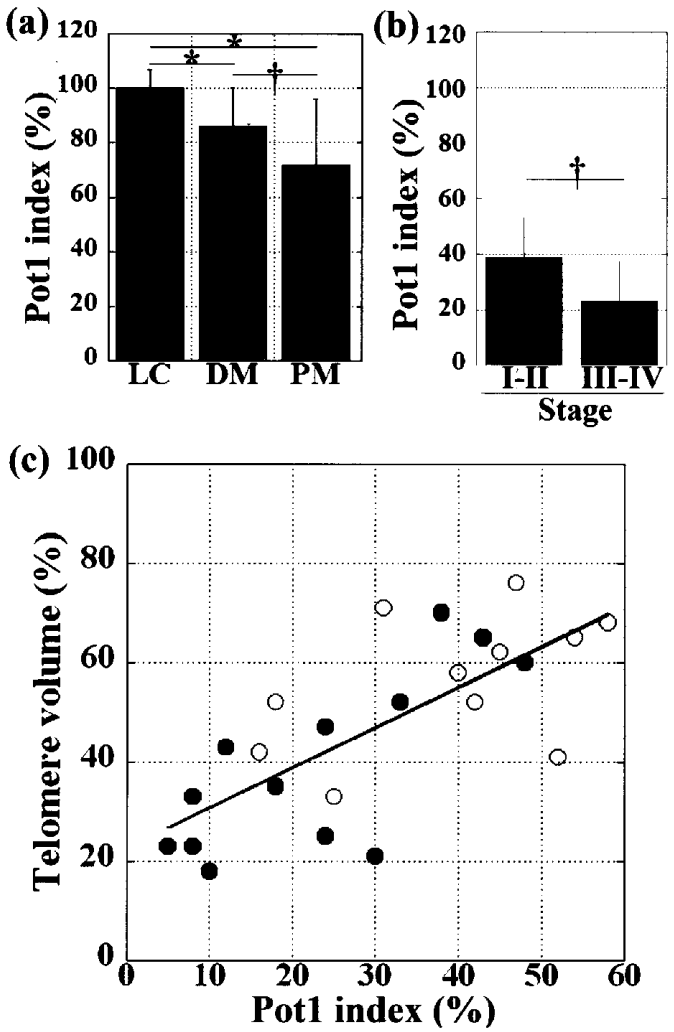

Figure 4. Pot1 positivity and telomere volume in human gastric mucosa and cancer. (a) Pot1 positivity in: lymphocytes (LC), mucosa distant from the tumor (DM), peritumoral mucosa (PM). (b) Pot1 positivity in stage I-II and stage III-IV cases. ${ }^{*} \mathrm{P}<0.0005,{ }^{\dagger} \mathrm{P}<0.05$; error bar, SD. (c) Correlation between Pot 1 positivity and telomere volume in gastric carcinomas. Telomere volume was designated as a percentage of that in lymphocytes. o, stage I-II; •, stage III-IV. Spearman R=0.7137, P<0.0001.

Immunohistochemistry of Potl in gastric mucosa and cancer. The Pot 1 index was examined in non-cancerous gastric mucosa by immunohistochemistry (Fig. 3a and b). In mucosal epithelial cells distant from the tumors, the Pot1 index was reduced to $84 \pm 14 \%$ of that in the infiltrating lymphocytes $(\mathrm{P}=0.0003$, Fig. $3 \mathrm{a}$ and Fig. $4 \mathrm{a})$. In contrast, the Pot1 index was more reduced in the epithelial cells in the peritumoral mucosa (within $5 \mathrm{~mm}$ from the tumoral periphery), to $72 \pm 24 \%$ of that in the infiltrating lymphocytes ( $\mathrm{P}=0.0001$, Fig. $3 \mathrm{~b}$ and Fig. $4 \mathrm{a}$ ). The Pot1 index was significantly lower in the epithelial cells in the peritumoral mucosa than those in the mucosa distant from the tumors $(\mathrm{P}<0.05)$.

Next, the Pot 1 index was examined in cancer tissues by immunohistochemistry (Fig. 3c and d, Table II). In Stage I-II gastric cancer, the Pot1 index was reduced to $39 \pm 14 \%$ of that in the infiltrating lymphocytes $(\mathrm{P}<0.0001$, Fig. $4 \mathrm{~b})$. It was more reduced in Stage III-IV gastric cancer, to $23 \pm 14 \%$ of that in the infiltrating lymphocytes $(\mathrm{P}<0.0001$, Fig. $4 \mathrm{~b})$. Pot 1 positivity was significantly lower in stage III-IV cancers than in stage I-II cancers $(\mathrm{P}<0.05)$. We compared Pot 1 positivity and telomere volume in the cases (Fig. 4c). The two parameters were significantly correlated in a linear regression manner (Spearman $\mathrm{R}=0.7137, \mathrm{P}<0.0001)$.

Finally, we compared the Pot 1 index and clinicopathological parameters (Table III). The 24 gastric cancer cases were divided into two groups by Pot1 index: Pot1-low (12 cases with lower Pot1 index) and Pot1-high (12 cases with higher 
Table III. Comparison of Pot 1 index with clinicopathological parameters in 24 gastric cancer cases.

\begin{tabular}{|c|c|c|c|}
\hline & $\begin{array}{l}\text { Pot1 high } \\
(\mathrm{n}=12)\end{array}$ & $\begin{array}{l}\text { Pot1 low } \\
(\mathrm{n}=12)\end{array}$ & $\mathrm{P}$ \\
\hline Pot1 index $(\%)$ & $\begin{array}{c}31-58(\text { median } 44) \\
44.3 \pm 8.2\end{array}$ & $\begin{array}{c}5-30(\text { median } 17) \\
16.5 \pm 8.0\end{array}$ & $<0.0001$ \\
\hline Telomere volume $(\%)^{\mathrm{a}}$ & $\begin{array}{c}41-76(\text { median } 63.5) \\
61.7 \pm 9.8\end{array}$ & $\begin{array}{c}18-52(\text { median } 33) \\
32.9 \pm 11.2\end{array}$ & 0.0001 \\
\hline Age (years) & $\begin{array}{c}48-81(\text { median } 64) \\
64.0 \pm 9.9\end{array}$ & $\begin{array}{c}\text { 43-78 (median } 66.5) \\
63.8 \pm 11.3\end{array}$ & NS \\
\hline Gender (M:F) & $7: 5$ & $7: 5$ & NS \\
\hline Pathological stage (I-II vs III-IV) & $7: 4$ & $4: 8$ & NS \\
\hline T-factor ${ }^{\mathrm{b}}$ (T1-T2:T3) & $11: 1$ & $5: 7$ & $<0.0500$ \\
\hline $\mathrm{N}-$ factor $^{\mathrm{b}}$ (N0:N1-N2) & $6: 6$ & $4: 8$ & NS \\
\hline M-factor ${ }^{\mathrm{b}}$ (M0:M1) & $12: 0$ & $9: 3$ & NS \\
\hline Histologyc (intestinal vs diffuse type) & $8: 4$ & $5: 7$ & NS \\
\hline
\end{tabular}

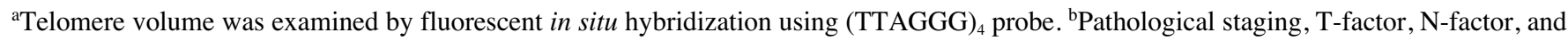
M-factor (all positive cases showed peritoneal dissemination in this study) were defined according to the TNM classification system (17). 'Histological classification was done according to Lauren's classification (18). NS, not significant.

Pot1 index). The Pot1 indexes of Pot1-low and Pot1-high groups were $16.5 \pm 8.0 \%$ and $44.3 \pm 8.2 \%$, respectively $(\mathrm{P}<0.0001)$. The telomere volumes in the Pot1-high group were higher $(61.7 \pm 9.8 \%)$ than those in the Pot1-low group $(32.9 \pm 11.2 \%)(\mathrm{P}=0.0001)$. There was no difference between the two groups in age, gender, pathological stage, $\mathrm{N}$-factor (nodal metastasis), M-factor (peritoneal dissemination), and histological types; however, T-factor (invasive depth) was advanced in Pot1-low. The number of T3 cases (invading the serosa) was 7 out of $12(58 \%)$ in the Pot1-low group, and, in contrast, 1 out of $12(8 \%)$ in the Pot1-high group $(\mathrm{P}<0.05)$.

\section{Discussion}

We confirmed that Pot 1 expression was closely correlated with telomere length in gastric cancer cells and human lymphocytes. Pot1 was localized to the t-loops of telomeres in the interphase nuclei of human cells $(10,11)$. We confirmed Pot1 intracellular localization by the fractionated cellular proteins. Pot 1 was found in the nuclear and cytosol fractions in MKN28 cells cultured in regular conditions, whereas it was mainly found in the nuclear fraction in nocodazoletreated MKN28 cells, whose cell cycle was stopped at G2/M. This observation suggests that Pot1 might be recruited into the nuclei in the G2/M phase to bind to telomeres. The Pot 1 localization detected by immunohistochemistry was found in whole nuclei or the nuclear periphery. This is similar to that of the telomeres in our previous observations (5), which suggests the co-localization of Pot1 and telomeres.

Immunohistochemical examination of the Pot 1 index in gastric mucosa and cancer showed that it was reduced in gastric epithelia and gastric cancer in comparison with infiltrated lymphocytes. Cancer cells showed a lower Pot1 index than gastric epithelia. To confirm the relationship of Pot1 positivity with telomere reduction, we compared Pot1 positivity and our previous data for telomere volume in the same cases (5). The results showed significant correlation between the two parameters and suggest that Pot 1 expression corresponds to telomere length in the cells or tissues.

Notably, the Pot1 index was significantly lower in the gastric epithelium adjacent to the tumoral periphery than in epithelia distant from the tumor. Two possibilities are proposed. One is that it was affected by the tumor: the mucosa adjacent to colon cancer showed hyperplastic, proliferative, and angiogenic properties, which were responses to the growth factors and cytokines produced by cancer cells (21). Another is that it is a precancerous change leading to gastric cancer. Telomere reduction is a strong stimulus for the reactivation of telomerase in somatic cells and is associated with carcinogenic processes in many cancers $(3,22)$. Pot 1 decrease might be associated with telomerase activation and hence with the transformation of gastric epithelia. In further study, we will endeavour to detect earlystage gastric cancer by examining Pot 1 expression as a probe.

\section{Acknowledgments}

This work was supported in part by a Grant-in-Aid for Scientific Research (C) from the Japan Society for the Promotion of Science, Japan.

\section{References}

1. Harley CB: Human aging and telomeres. Ciba Found Symp 211: 129-139, 1997. 
2. Greider CW and Blackburn EH: Telomeres, telomerase and cancer. Sci Am 274: 92-97, 1996.

3. Holt SE, Wright WE and Shay JW: Multiple pathways for the regulation of telomerase activity. Eur J Cancer 33: 761-766, 1997.

4. Weng NP, Palmer LD, Levine BL, Lane HC, June CH and Hodes RJ: Tales of tails: regulation of telomere length and telomerase activity during lymphocyte development, differentiation, activation, and aging. Immunol Rev 160: 43-54, 1997.

5. Kuniyasu H, Kitadai Y, Mieno H and Yasui W: Helicobactor pylori infection is closely associated with telomere reduction in gastric mucosa. Oncology 65: 275-282, 2003.

6. Kuniyasu H, Domen T, Hamamoto T, Yokozaki H, Yasui W, Tahara $\mathrm{H}$ and Tahara E: Expression of human telomerase RNA is an early event of stomach carcinogenesis. Jpn J Cancer Res 88: 103-107, 1997.

7. Tahara H, Kuniyasu H, Yokozaki H, Yasui W, Shay JW, Ide T and Tahara E: Telomerase activity in preneoplastic and neoplastic gastric and colorectal lesions. Clin Cancer Res 1: 1245-1251, 1995.

8. Baumann P and Cech TR: Pot1, the putative telomere end-binding protein in fission yeast and humans. Science 292: 1171-1175, 2001.

9. Lei M, Baumann P and Cech TR: Cooperative binding of single-stranded telomeric DNA by the Pot 1 protein of Schizosaccharomyces pombe. Biochemistry 41: 14560-14568, 2002.

10. Baumann P, Podell E and Cech TR: Human Pot1 (protection of telomeres) protein: cytolocalization, gene structure, and alternative splicing. Mol Cell Biol 22: 8079-8087, 2002.

11. Wei $\mathrm{C}$ and Price CM: Cell cycle localization, dimerization, and binding domain architecture of the telomere protein cPot1. Mol Cell Biol 24: 2091-2102, 2004

12. Loayza D and De Lange T: POT1 as a terminal transducer of TRF1 telomere length control. Nature 423: 1013-1018, 2003.

13. Colgin LM, Baran K, Baumann P, Cech TR and Reddel RR: Human POT1 facilitates telomere elongation by telomerase. Curr Biol 13: 942-946, 2003.
14. Ye JZ, Hockemeyer D, Krutchinsky AN, Loayza D, Hooper SM, Chait BT and De Lange T: POT1-interacting protein PIP1: a telomere length regulator that recruits POT1 to the TIN2/TRF1 complex. Genes Dev 18: 1649-1654, 2004.

15. Kondo T, Oue N, Yoshida K, Mitani Y, Naka K, Nakayama H and Yasui W: Expression of POT1 is associated with tumor stage and telomere length in gastric carcinoma. Cancer Res 64: 523-529, 2004.

16. Lin X, Gu J, Lu C, Spitz MR and Wu X: Expression of telomere-associated genes as prognostic markers for overall survival in patients with non-small cell lung cancer. Clin Cancer Res 12: 5720-5725, 2006.

17. Sobin LH and Wittekind C (eds): UICC TNM Classification of Malignant Tumours. 6th edition, John Wiley \& Sons Inc., New York, 2003.

18. Lauren P: The two histological main types of gastric carcinoma: diffuse and so-called intestinal-type carcinoma. An attempt at a histo-clinical classification. Acta Pathol Microbiol Scand 64: 31-49, 1965.

19. Kuniyasu H, Yasui W, Kitahara K, Naka K, Yokozaki H, Akama Y, Hamamoto T, Tahara H and Tahara E: Growth inhibitory effect of interferon-beta is associated with the induction of cyclin-dependent kinase inhibitor p27Kip1 in a human gastric carcinoma cell line. Cell Growth Differ 8: 47-52, 1997.

20. Kuniyasu H, Oue N, Wakikawa A, Shigeishi H, Matsutani N, Kuraoka K, Ito R, Yokozaki H and Yasui W: Expression of receptors for advanced glycation end-products (RAGE) is closely associated with the invasive and metastatic activity of gastric cancer. J Pathol 196: 163-170, 2002.

21. Kuniyasu $\mathrm{H}$, Yasui W, Shinohara $\mathrm{H}$, Yano $\mathrm{S}$, Ellis LM, Wilson MR, Bucana CD, Rikita T, Tahara E and Fidler IJ: Induction of angiogenesis by hyperplastic colonic mucosa adjacent to colon cancer. Am J Pathol 157: 1523-1535, 2000.

22. Greider CW: Telomere length regulation. Annu Rev Biochem 65: $337-365,1996$ 